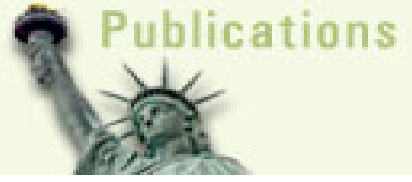

American Journal of Environmental Sciences 4 (1): 39-49, 2008

ISSN 1553-345X

(C) 2008 Science Publications

\title{
A Preliminary Investigation into the Environmental Awareness of the Omani Public and their Willingness to Protect the Environment
}

\author{
Sabah A. Abdul-Wahab \\ Mechanical and Industrial Engineering Department, Sultan Qaboos University, P.O. Box 33, Al Khoud, \\ P.C. 123, Muscat, Sultanate of Oman
}

\begin{abstract}
This study was conducted with the objective of evaluating the present status of environmental awareness of Omani citizens and their willingness to contribute to environmental protection. The focus of the study was to investigate the Omani public's level of knowledge about general basic and current local and international environmental issues and to find out their environmental attitudes and behaviors towards their environment. This information was gathered through a survey questionnaire with its structure constructed for this purpose. The survey questionnaire consisted of various current topics regarding the environment. It was primarily designed to assess the level of residents' environmental awareness from three aspects: environmental knowledge, environmental attitudes, and environmental behaviors. This questionnaire was administered to 425 respondents who were evenly distributed among all areas of the entire Muscat governorate in Oman during January 2007. The results of the survey showed that the basic environmental knowledge of the public was generally lacking, whereas their local and international environmental knowledge were found to be higher. In contrast, the study found that the public had a higher level of environmental attitudes and behaviors, but also noted that the public achieved a higher score in their environmental attitudes than in their environmental behaviors. The results of the survey and recommendations of the study are hoped to be used in the evaluation of the effectiveness of the current public awareness strategies and programmes and in the design future programmes by government authorities and civil service groups.
\end{abstract}

Key words: Designing environmental policies, environmental awareness, environmental public survey, Sultanate of Oman

\section{INTRODUCTION}

Fifteen years have elapsed since the Rio Summit (in Rio De Janeiro in 1992) and the publication of the Agenda 21 Report as a blue print for countries to pursue Sustainable Development ${ }^{[1]}$. The Sultanate of Oman, as most countries in the region, has reacted by restructuring the environmental administrative infrastructure and the replacement of the Higher Council for the Environment with the Ministry of Regional Municipalities and Environment (1991). In order to increase geographic coverage and effectiveness, the Ministry was expanded to become the Ministry of Regional Municipalities, Environment and Water Resources (2001). The Manpower that the Musicality and the Water Resources Administration brought in allowed the newly established ministry to reach out the various cities, towns and villages in the Sultanate. The media often declares that environmental issues and environmental problems in the Sultanate of Oman have gained more public attention in the last few decades. However, no specific research had been undertaken to investigate the level of environmental awareness of the public and to find out their attitudes towards the environment.

Studies have shown that determining what people know about the environment, how they feel about it, and what actions they take that may help or harm the environment is critical to establishing the sustainability of a community ${ }^{[2]}$. Ramsey et al. ${ }^{[3]}$ demonstrated that environmental awareness is the first major step in preparing people to solve environmental problems. Accordingly, in the last few decades, environmental problems have been approached with regards not only to their technical and economic dimensions but also in their societal dimensions ${ }^{[4]}$. In this approach, solutions to environmental problems were found to lie in the alteration of human attitudes (i.e., perceptions or values

Corresponding Author: Sabah A. Abdul-Wahab, Mechanical \& Industrial Engineering Department, Sultan Qaboos University, P.O. Box 33, Al Khoud, P.C. 123, Muscat, Sultanate of Oman 
Am. J. Environ. Sci., 4 (1): 39-49, 2008

about given environmental issues) and behavior ${ }^{[4]}$. The perception and understanding of social attitudes and behaviors can be the bases for constituting the national environmental policy and advancing the improvement of the environmental administration system ${ }^{[5-10]}$. In turn, this may reflect upon economic and social activities. This means that the environmental crisis faced by most countries, including developing countries, and technological solution and economic measures can only be successfully introduced and take effect public perception and demand exists. This has been confirmed in several studies in both developing and developed countries ${ }^{[10-16]}$.

Therefore, a study was conducted with the focus of assessing the public environmental awareness in Oman and their willingness to protect the environment. The public were administered a questionnaire to assess their environmental awareness in terms of three aspects: environmental knowledge, environmental attitudes, and environmental behaviors. The study was conducted in January 2007 and the survey covered the entire Muscat governorate. This paper summarizes the results of the preliminary study, focusing on assessing the levels of environmental knowledge, attitudes and behaviors and the extent of efforts needed in raising public interest, knowledge and patterns of behavior to the environment and achieving sustainable development.

\section{MATERIALS AND METHODS}

A survey questionnaire designed to evaluate the environmental awareness of the public in the Sultanate of Oman, was self administered to 425 randomly selected respondents during January 2007. The respondent was asked to fill out the questionnaire and answer all the questions.

The first section of the questionnaire was related to general environmental knowledge. Respondents were asked to assess their knowledge about general environmental issues, through answering 15 multiplechoice questions on a variety of general and current environmental issues. Four possible choices were given for each question and one answer was correct.

The second section was constructed to measure the public's attitudes toward the protection of the environment. Respondents were asked to assess their environmental attitudes.

In the third section of the questionnaire, respondents were asked to assess their environmental behaviors towards the environment and their level of participation in pro-environmental behaviors.
The data collected were grouped and categorized. Statistical analysis was carried out by using the Statistical Package for Social Science (SPSS).

\section{RESULTS AND DISCUSSION}

A total of 425 respondents from all areas of the Muscat governorate were surveyed in this study. Table 1 gives the basic demographic information of the respondents obtained from the survey. With respect to sex, $58.4 \%$ of the sample was male while $41.6 \%$ was female. With regard to age, $49.2 \%$ of the respondents were under 20 years old, $33.9 \%$ were between $21-30$ and $11.5 \%$ were between $31-40$. The rest of the respondents were older than 41 years old (5.4\%). With respect to educational level, $43.0 \%$ of the respondents reported they possess university level education, while $47.4 \%$ indicated they achieved only secondary level education. The rest of the sample indicated they possessed a technical (5.1\%), middle school (3.9\%), or primary $(0.6 \%)$ education level. With regard to family income compared to the standard of living in the country, $70.2 \%$ of the respondents said they have average income (middle-class), 22.2\% above average and $7.1 \%$ below average. Respondents were also asked to identify their smoking habits. Of the sample, $88.0 \%$ said they do not smoke and $3.8 \%$ said they always smoke. The rest of the respondents said they smoke sometimes $(4.4 \%)$ or when in the mood $(3.8 \%)$.

Environmental Knowledge: Table 2 shows results for each of the fifteen multiple-choice questions by number and percentage of the respondents with correct and incorrect answers (the correct answer for each question is underlined in Table 2). It can be seen that the majority of respondents to the survey were able to answer questions correctly. The mean percentage of correct answers for all questions among the respondents was found $68.8 \%$. More than half of the respondents gave incorrect answers to very basic questions. Correct answers about basic environmental questions ranged from $43.3 \%$ to $48.2 \%$, depending on the question. For instance, only $44.5 \%$ of the respondents knew that the percentage of oxygen in the atmosphere is less than $25 \%$. Also, less than $50 \%$ of the respondents $(45.8 \%)$ knew that the percentage of nitrogen in the atmosphere is more than $75 \%$. When asked about the effect of the increase of ozone gas in the atmosphere, less than half of the respondents were able to give the correct answer $(48.2 \%)$. 
Am. J. Environ. Sci., 4 (1): 39-49, 2008

Table 1: Demographic information of respondents $(n=425)$

\begin{tabular}{|c|c|c|c|c|c|}
\hline \multirow[t]{2}{*}{ Demographic } & \multirow[b]{2}{*}{ \# } & \multirow[b]{2}{*}{$(\%)$} & \multicolumn{2}{|c|}{ Total responses } & \multirow{2}{*}{$\begin{array}{l}\text { No response } \\
\#\end{array}$} \\
\hline & & & Total & $(\%)$ & \\
\hline Sex & & & 423 & $(100.0)$ & 2 \\
\hline Male & 247 & $(58.4)$ & & & \\
\hline Female & 176 & (41.6) & & & \\
\hline Age & & & 410 & $(100.0)$ & 15 \\
\hline Under 20 & 202 & $(49.2)$ & & & \\
\hline $21-30$ & 139 & (33.9) & & & \\
\hline $31-40$ & 47 & $(11.5)$ & & & \\
\hline $41-50$ & 16 & $(3.9)$ & & & \\
\hline 51 and over & 6 & $(1.5)$ & & & \\
\hline Education level & & & 409 & $(100.0)$ & 16 \\
\hline Primary & 2 & $(0.6)$ & & & \\
\hline Middle school & 16 & (3.9) & & & \\
\hline Secondary & 194 & $(47.4)$ & & & \\
\hline Technical & 21 & $(5.1)$ & & & \\
\hline University & 176 & $(43.0)$ & & & \\
\hline $\begin{array}{l}\text { Family income compared to the } \\
\text { standard of living in the country }\end{array}$ & & & 406 & $(100.0)$ & 19 \\
\hline Above average & 90 & $(22.2)$ & & & \\
\hline Average & 287 & (70.7) & & & \\
\hline Below average & 29 & (7.1) & & & \\
\hline Smoking & & & 366 & $(100.0)$ & 59 \\
\hline Yes always & 14 & $(3.8)$ & & & \\
\hline No & 322 & $(88.0)$ & & & \\
\hline Sometimes & 16 & $(4.4)$ & & & \\
\hline When in the mood & 14 & $(3.8)$ & & & \\
\hline Total cases & 425 & $100 \%$ & & & \\
\hline
\end{tabular}

Further, only $43.3 \%$ of the respondents correctly identified pollutants from car exhausts as more dangerous to human health than pollutants from industrial stacks. Less than half of the respondents $(46.8 \%)$ correctly answered very basic questions about the positive effect environmental impact studies can have on the environment.

Respondents were knowledgeable about international environmental problems such as climate change, global warming and the depletion of the ozone layer (i.e., questions 8,9 and 15). Correct answers about international environmental questions ranged from $66.2 \%$ to $78.7 \%$, depending on the question. This is probably because the public are often exposed to such issues through TV programs, daily newspapers and the internet compared to basic environmental issues that are mostly discussed at schools. Many previous studies indicated a relationship between the use of mass media and environmental knowledge ${ }^{[14]}$. It was shown that mass media play an important role in shaping public opinion through television, radio and the press, and television in particular was shown to be a powerful instrument for changing public attitudes. Christine ${ }^{[17]}$ found that news programs were effective at increasing level of environmental knowledge among those who watched the program. Schultz ${ }^{[18]}$ reported the role of mass media in recognition of environmental problems. It was also noticeable that respondents were knowledgeable about local environmental problems such as pollution due to car exhausts and industrial plants (e.g., questions 3, 4, 7, 10 and 14). Correct answers about such questions ranged from $73.6 \%$ to $95.3 \%$, depending on the question. This is probably because such problems are directly related to human health. In addition, the media such as television and newspapers might play an important role in increasing residents' awareness and knowledge of local environmental issues. For instance, the great majority of respondents (95.3\%) were able to identify carbon monoxide as the primary gas emitted by car exhausts. 
Am. J. Environ. Sci., 4 (1): 39-49, 2008

Table 2: Environmental knowledge (multiple-choice) questions (correct answer is underlined)

\begin{tabular}{|c|c|c|c|c|c|c|c|c|}
\hline \multirow{2}{*}{ \# } & \multirow{2}{*}{ Question } & \multicolumn{2}{|c|}{ Correct } & \multicolumn{2}{|c|}{ Incorrect } & \multicolumn{2}{|c|}{ Total responses } & \multirow{2}{*}{$\begin{array}{l}\text { No } \\
\text { respon } \\
\text { Total }\end{array}$} \\
\hline & & Total & $(\%)$ & Total & $(\%)$ & Total & $(\%)$ & \\
\hline 1 & $\begin{array}{l}\text { Is species extinction (plants and/or animals) a form } \\
\text { of environmental pollution? (yes, no, no relation). }\end{array}$ & 292 & $(74.5)$ & 100 & $(25.5)$ & 392 & $(100.0)$ & 33 \\
\hline 2 & $\begin{array}{l}\text { What do you think the effect of the increase of } \\
\text { ozone gas in the atmosphere is? (harmful, helpful, it }\end{array}$ & 170 & $(48.2)$ & 183 & $(51.8)$ & 353 & $(100.0)$ & 72 \\
\hline 3 & $\begin{array}{l}\text { Is there a relation between the concentration of } \\
\text { pollutants in the air with the dominant weather }\end{array}$ & 287 & (73.6) & 103 & (26.4) & 390 & $(100.0)$ & 35 \\
\hline 4 & $\begin{array}{l}\text { Factories (ie. industrial plants) that are established } \\
\text { without conducting an environmental impact study }\end{array}$ & 357 & $(88.6)$ & 46 & (11.4) & 403 & $(100.0)$ & 22 \\
\hline 5 & $\begin{array}{l}\text { What is the oxygen ratio in the atmosphere (less } \\
\text { than } 25 \%, 50 \% \text {, more than } 75 \% \text { ). }\end{array}$ & 182 & $(44.5)$ & 211 & $(55.5)$ & 393 & $(100.0)$ & 32 \\
\hline 6 & $\begin{array}{l}\text { What is the nitrogen ratio in the air (less than } 25 \% \text {, } \\
50 \% \text {, more than } 75 \% \text { ). }\end{array}$ & 174 & $(45.8)$ & 206 & $(54.2)$ & 380 & $(100.0)$ & 45 \\
\hline 7 & $\begin{array}{l}\text { Which gases are emitted by car exhausts? (carbon } \\
\text { monoxide, ozone ). }\end{array}$ & 387 & $(95.3)$ & 19 & $(4.7)$ & 406 & $(100.0)$ & 19 \\
\hline 8 & $\begin{array}{l}\text { Is climate change an international environmental } \\
\text { problem (yes, no). }\end{array}$ & 288 & (71.6) & 114 & (28.4) & 402 & $(100.0)$ & 23 \\
\hline 9 & $\begin{array}{l}\text { Is global warming an international environmental } \\
\text { problem (yes, no, no relation). }\end{array}$ & 270 & $(66.2)$ & 138 & $(33.8)$ & 408 & $(100.0)$ & 17 \\
\hline 10 & $\begin{array}{l}\text { Is there a relationship between work-related diseases } \\
\text { and industrial pollution (yes, no, no relation). }\end{array}$ & 312 & $(78.6)$ & 85 & (21.4) & 397 & $(100.0)$ & 28 \\
\hline 11 & $\begin{array}{l}\text { What is the relationship between the environment } \\
\text { and saving energy (harmful, helpful, no relation). }\end{array}$ & 242 & $(62.5)$ & 145 & $(37.5)$ & 387 & $(100.0)$ & 38 \\
\hline 12 & $\begin{array}{l}\text { What effect can environmental impact studies } \\
\text { (conducted prior to the establishment of new }\end{array}$ & 66 & $(46.8)$ & 75 & $(53.2)$ & 141 & $(100.0)$ & 284 \\
\hline 13 & $\begin{array}{l}\text { Which one is more dangerous to human health: } \\
\text { industrial chimney stacks or pollutants from car }\end{array}$ & 173 & $(43.3)$ & 227 & $(56.7)$ & 400 & $(100.0)$ & 25 \\
\hline 14 & $\begin{array}{l}\text { How has overpopulation in Muscat affected the } \\
\text { increase of pollution from car exhausts? (bad, good, }\end{array}$ & 373 & $(94.0)$ & 24 & $(6.0)$ & 397 & $(100.0)$ & 28 \\
\hline \multirow[t]{2}{*}{15} & $\begin{array}{l}\text { The agreement on the Montreal Protocol, which } \\
\text { focused on minimizing ozone layer depletion, took }\end{array}$ & 288 & $(78.7)$ & 78 & $(21.3)$ & 366 & $(100.0)$ & 59 \\
\hline & Total & 3861 & $(68.8)$ & 1754 & $(31.2)$ & 5615 & $(100.0)$ & 760 \\
\hline
\end{tabular}

The principal conclusion emerging from the data analysis of the Table 2 was that it is important to increase the public's basic environmental knowledge. The Ministry of Regional Municipalities, Environment and Water Resources, therefore, should hold more public hearings on major issues, new big projects and when there is environmental crisis. Also, it is suggested that more attention needs to be paid to educate students of all school levels toward environmental issues. It should start at the very early stage of education. As noted by Ramsey and Rickson $^{[19]}$, all individuals should be given more environmental knowledge in order to be able to change their environmental attitudes and behavior. Bradley et al. ${ }^{[20]}$ assesses the environmental knowledge and attitudes of high school students before and after exposure to a 10-day environmental science course. The results of the authors indicated significant differences in both knowledge gain and attitudes of students after exposure. Students' environmental knowledge rates increased by $22 \%$ after they completed the environmental science course. In addition, students' environmental attitudes became more environmentally favorable.

Environmental Attitudes: Many questions were asked to assess the attitudes and the opinions of respondents on various environmental issues. These questions mainly concentrate on people's satisfaction with their surroundings and the environmental protection work of the government. Overall, it can be noted that respondents had high positive attitudes toward the 
environment. Of the respondents, $90.5 \%$ believed that people who pollute the environment should be punished. Although the majority of the respondents (68.1\%) were optimistic in believing that it is possible to create future generations that treat the environment with respect, $27.0 \%$ of the respondents indicated that it can be done but with some difficulty.

Over half of the sample $(58.7 \%)$ believed that increasing the cost of electricity is a suitable government strategy to reduce people's electricity consumption. The great majority of respondents $(82.6 \%)$ believed that air pollution in Muscat and surrounds is an important issue with dangerous consequences. Respondents indicated that the effects of air pollution are observable on buildings and facilities $(32.9 \%)$, on cars $(32.1 \%)$, and on air conditioners $(19.9 \%)$. The results of the survey showed that the majority of respondents $(92.7 \%)$ agreed that smoking cigarettes and Sheesha (water pipe) inside the house pollutes the house environment. The great majority of respondents $(91.4 \%)$ believed that there has been an increase in smoking in Muscat and $93.2 \%$ of the respondents indicated that such smoke constitutes air pollution.

While $84.2 \%$ of the respondents believed that there has been an increase in the use of insecticides in Muscat, almost half of the respondents (49.9\%) said that this increase has harmed the environment.

Most of the respondents $(60.1 \%)$ found that the state of the environment in the area where they live has improved over the past ten years, while $24.5 \%$ thought that it did not change. The rest of the respondents said that the state of the environment has deteriorated $(15.4 \%)$.

The majority of respondents $(82.2 \%)$ believed that the government should increase current efforts to protect the environment in Muscat while 16.1\% thought the government should maintain current efforts to protect the environment. Only a small percentage of the respondents $(1.7 \%)$ thought the government should reduce current efforts as the individuals also have a responsibility to protect the environment with the government. According to the survey done by Louis Harris and Associates ${ }^{[21]}$, both general public and leaders are feeling that environmental conditions have worsened compared to the past and are aware of harmful effect of environmental degradation on health. Most people believe something must be done and environmental protection should be the major governmental priority.

One of the questions on the survey asked respondents to answer yes or no regarding whether or not they believed using cloth bags instead of plastic bags would protect the environment. The percentage of those who answered yes was $59.1 \%$ as compared to $31.3 \%$ of the respondents who said no. The rest of the respondents $(9.6 \%)$ reported that there is no relation between using cloth bags and protecting of the environment. This may be encouraging as a possible indicator that the public may still be willing to retain the traditional ways of carrying groceries.

While $95.6 \%$ of the respondents thought that Muscat is overpopulated, only $77.9 \%$ said that this overpopulation in Muscat has harmed the environment. Of the respondents, $40.8 \%$ found the effect of industrial growth on the environment of Muscat is harmful. Half of the respondents $(54.6 \%)$ considered the effect of urban expansion and the current lifestyle in Muscat as harmful to the environment.

Almost all the respondents (99.5\%) believed that there has been an increase in the number of cars in Muscat. However, only $83.5 \%$ of the sample found that this increase has harmed the environment. In addition, the great majority of respondents believed that there is now pressure on the main facilities in Muscat and $69.8 \%$ of the sample considered this pressure to be harmful.

Of the respondents, $82.0 \%$ agreed with the theory of the protection of the environment from humans while fewer respondents $(18.0 \%)$ agreed with the theory of the protection of humans from the environment. This reflects that the public are concerned about environmental deterioration and wants to see something done about it.

Nearly half of the respondents (51.4\%) believed that directing environmental education at youth would provide greater benefits than environmental education of seniors. The remainder of the respondents either disagreed $(35.4 \%)$ or said there is no difference (13.2\%). Environmental education is important in promoting environmental awareness and protection. Because early attitudes and knowledge shape later thinking and because attitudes do not change easily, there will always be a great need to assess the developing of environmental attitude and knowledge during childhood ${ }^{[22]}$.

Table 3 summarizes other attitude questions used to assess the opinions of the public towards various environmental issues that are related directly to their health. The results shown in Table 3 demonstrated that the public are aware of the environmental problems that are directly related to their health. When asked to select 3 diseases that their families suffer from now that they believe are related to the air pollution in Muscat, respondents considered the asthma crisis as the most related disease $(20.5 \%)$, followed by chest allergies 
especially in children (17.7\%), and inflammation and redness of eyes (16.0\%). Other diseases considered by respondents were breathing difficulties $(13.2 \%)$, a skin itch $(12.0 \%)$, an increase in coughing or a runny nose $(8.3 \%)$, sinusitis $(6.9 \%)$ and chest diseases $(5.4 \%)$.

When asked to select the 3 most important domestic sources of environmental pollution, $25.4 \%$ of the respondents selected smoking, $22.0 \%$ selected vapours, fumes and gases in the kitchen and $20.1 \%$ selected detergents and various volatile chemical substances.

When asked to select the 3 causes of environmental pollution in Muscat, respondents selected environmentally unfriendly behavior as the most important cause (22.9\%), followed by lack of environmental awareness among some citizens (22.1\%) and lack of commitment to environmental legislation $(16.0 \%)$. It is worth noting that the percentage of the respondents who selected lack of commitment to environmental legislation (16.0\%) was higher than those who selected lack of environmental legislation $(8.9 \%)$. This is a clear message that people consider the main problem to be lax law enforcement rather than the law itself. It is also a message from the public indicating that the most significant factor affecting environment is not the official environmental policy but the public's willingness to take care of the environment $^{[19]}$.

When asked to select the 5 most important causes of air pollution in Muscat, respondents identified car exhausts as the most important cause (15.3\%), followed by environmentally unfriendly practices or attitudes (9.6\%), industrial plant stacks $(9.2 \%)$, dust $(8.2 \%)$, landfills (7.7\%) and waste treatment plants (7.4\%).

When asked to select the 3 most useful methods to increase environmental awareness, respondents considered television $(24.7 \%)$ as the most important method followed by education curricula at colleges and universities (22.9\%) and education campaigns \& schools (12.2\%). Other methods selected by respondents were magazines $(10.2 \%)$ and radio $(9.8 \%)$.

Environmental behavior: Table 4 shows the questions asked to assess the willingness of the respondents to take a variety of actions to protect the environment and their readiness to commit to environmental legislation. The vast majority of the respondents (85.2\%) thought that they did not carry out any negative behavior towards the environment and nature. Yet only $40.6 \%$ were willing to change their lifestyle and participate in an environmental campaign that promotes the use of public transport (e.g., buses) instead of personal transport (e.g., car) to reduce air pollution.

While $88.4 \%$ of the respondents said they were ready to commit to environmental legislation, only $62.4 \%$ said that they participated in environmental activities. Only $12.7 \%$ of respondents said they always watch TV programs or read material about the environment compared to $8.4 \%$ of the respondents who indicated null interest. Over three quarters of the sample, (78.9\%) said that they sometimes watch TV programs or read material about the environment.

The television and daily newspapers were the most frequently used media for environmental information for most respondents. The majority of respondents said that their main source of environmental information was from television (26.8\%), followed by daily newspapers (20.9\%), internet (16.6\%), radio (11.4\%), general magazines $(10.0 \%)$ and environmental magazines $(9.95 \%)$. This was in line with previous studies which indicated that television and newspapers were the most frequently used media for environmental information $^{[23,24]}$.

While $35.5 \%$ said they were willing to participate in environmental education campaign, the majority of the respondents said that their willingness to participate in such activities depends on the type of participation.

The respondents were asked to select the five most important solutions to protect the environment.

Table 5 shows that the periodic inspection of industrial facilities (10.1\%) and creating a generation that respects the environment $(9.0 \%)$ ranked among the top two solutions suggested by the respondents being surveyed. The other three solutions reported by respondents were increase in the area of parklands (6.7\%), the establishment of an environmental police force and the enactment of strict laws (6.1\%) and environmental monitoring and the observation of air quality by national authorities $(6.0 \%)$. 
Table 3: Other environnemental attitudes' questions

\begin{tabular}{lll}
\hline$\# \quad$ Item & Total & $(\%)$ \\
\hline 1 & $\begin{array}{l}\text { Are there specific diseases that you or your family suffer from now that you } \\
\text { believe are related to the air pollution in Muscat? }\end{array}$ & \\
If yes, choose 3 diseases only. & & \\
& & \\
The asthma crisis & 170 & $(20.5)$ \\
Chest allergies especially in children & 147 & $(17.7)$ \\
Inflammation and redness of eyes & 133 & $(13.2)$ \\
Breathing difficulties & 110 & $(12.0)$ \\
A skin itch & 100 & $(5.4)$ \\
Chest diseases & 45 & $(6.3)$ \\
An increase in coughing or a runny nose & 69 & \\
Sinusitis & 57 & \\
What are the most important domestic sources of environmental pollution & & \\
(choose 3 only). & & $(22.0)$ \\
Vapours, fumes, and gases in the kitchen & & $(17.7)$ \\
Smoking & 253 & $(20.1)$ \\
Germs and parasites found in dust & 292 & \\
Detergents and various volatile chemical substances & 204 & \\
& 231 & \\
Paints used in the house & & 172
\end{tabular}

3 Please select 3 causes of environmental pollution in Muscat.

Lack of environmental awareness amongst some citizens Environmentally unfriendly behavior

Lack of environmental education programs

Inadequate governmental expenditure for the environment

Lack of environmental legislation

Lack of commitment to environmental legislation

Lack of private sector investment in environmental protection

Contradictory decisions made by different authorities

Car exhausts

Industrial plant stacks

Waste containers, landfills

Dust

Gases from industries

Bad smells

Waste treatment plants

Environmentally unfriendly practices or attitudes (e.g. dumping dead 181

Lack of environmental awareness

Environmentally unfriendly disposal of industrial wastes by factories

Pressure on public facilities

Noise problems

Toxic wastes

Explosions for the purpose of building and construction

Depletion of the ozone layer

Factories that crush stones thus producing dust

Traffic jams

Open air incineration (e.g. burning wood, old car tyres)

Insecticides and fertilizers

Misuse of energy sources such as electricity and fuel 
Am. J. Environ. Sci., 4 (1): 39-49, 2008

5 What method should be used to increase environmental awareness? (choose

1184

$(100.0)$

3 only).

$\begin{array}{lll}\text { Education curricula at colleges and universities } & 271 & (22.9) \\ \text { Radio } & 116 & (9.8) \\ \text { Television } & 292 & (24.7) \\ \text { Magazines } & 121 & (10.2) \\ \text { Conferences and seminars } & 96 & (8.1) \\ \text { Exhibitions } & 84 & (7.1) \\ \text { Competitions } & 59 & (5.0) \\ \text { Education campaigns \& schools } & 145 & (12.2)\end{array}$

Table 4: Environmental behaviors' questions

\begin{tabular}{|c|c|c|c|c|c|c|}
\hline \multirow[t]{2}{*}{ \# } & \multirow[t]{2}{*}{ Behavior } & \multirow[t]{2}{*}{ Total } & \multirow[t]{2}{*}{$(\%)$} & \multicolumn{2}{|c|}{ Total responses } & \multirow{2}{*}{$\begin{array}{l}\text { No response } \\
\text { Total }\end{array}$} \\
\hline & & & & Total & $(\%)$ & \\
\hline \multirow[t]{3}{*}{1} & Do you carry out any negative behavior towards the & & & 406 & $(100.0)$ & 19 \\
\hline & $\begin{array}{l}\text { Pavimanmant and noturas frac nol } \\
\text { Yes }\end{array}$ & 60 & $(14.8)$ & & & \\
\hline & No & 346 & $(85.2)$ & & & \\
\hline \multirow[t]{3}{*}{2} & Do you participate in any environmental protection activities? & & & 409 & $(100.0)$ & 16 \\
\hline & & 255 & $(62.4)$ & & & \\
\hline & No & 154 & $(37.6)$ & & & \\
\hline \multirow[t]{3}{*}{3} & $\begin{array}{l}\text { Do you watch TV programs or read material about the } \\
\text { anvirnnment) (alxrave cometimas nn) } \\
\text { Always }\end{array}$ & 47 & (12.7) & 369 & $(100.0)$ & 56 \\
\hline & Sometimes & 291 & (78.9) & & & \\
\hline & No & 31 & (8.4) & & & \\
\hline \multirow[t]{9}{*}{4} & $\begin{array}{l}\text { What sources do you use to obtain environmental information? } \\
\text { (choose 3) }\end{array}$ & & & 1095 & $(100.0)$ & - \\
\hline & Daily newspapers & 229 & $(20.9)$ & & & \\
\hline & Environmental magazines & 109 & $(9.95)$ & & & \\
\hline & Radio & 125 & $(11.4)$ & & & \\
\hline & Television & 293 & $(26.8)$ & & & \\
\hline & Internet & 182 & $(16.6)$ & & & \\
\hline & General magazines & 110 & $(10.0)$ & & & \\
\hline & Books & 17 & $(1.6)$ & & & \\
\hline & Lectures & 30 & $(2.7)$ & & & \\
\hline \multirow[t]{4}{*}{5} & $\begin{array}{l}\text { Are you willing to participate in environmental education } \\
\text { camnairnc? (ves } n n \text { it denande on the turne of narticination) }\end{array}$ & & & 408 & $(100.0)$ & 17 \\
\hline & Yes & 145 & $(35.5)$ & & & \\
\hline & No & 92 & $(22.6)$ & & & \\
\hline & It depends on the type of participation & 171 & $(41.9)$ & & & \\
\hline \multirow[t]{3}{*}{6} & Are you willing to participate in an environmental campaign & & & 392 & $(100.0)$ & 33 \\
\hline & $\begin{array}{l}\text { that noramntas the uce of nuhlin tranenort fa o hucasl inctaad of } \\
\text { Yes }\end{array}$ & 159 & (40.6) & & & \\
\hline & No & 233 & $(59.4)$ & & & \\
\hline \multirow[t]{3}{*}{7} & Are you ready to commit to environmental legislation? (yes, & & & 412 & $9100.0)$ & 13 \\
\hline & Yes & 364 & $(88.4)$ & & & \\
\hline & No & 48 & (11.6) & & & \\
\hline
\end{tabular}


Am. J. Environ. Sci., 4 (1): 39-49, 2008

Table 5: Solutions selected by respondents for environmental protection

\begin{tabular}{|c|c|c|c|}
\hline \# & Solution & Total & $(\%)$ \\
\hline \multicolumn{2}{|r|}{ In your opinion, how can you protect the environment? Please select the five most important solutions only. } & 1832 & $(100.0)$ \\
\hline 1 & Periodic inspection of industrial facilities. & 185 & $(10.1)$ \\
\hline 2 & Achieving a balance between industry and the environment. & 96 & $(5.2)$ \\
\hline 3 & The rationalization of the reduction of the electrical energy consumption. & 97 & $(5.3)$ \\
\hline 4 & Increase in the area of parklands. & 122 & (6.7) \\
\hline 5 & Environmental monitoring and the observation of air quality by national authorities. & 109 & $(6.0)$ \\
\hline 6 & The establishment of an environmental police force and the enactment of strict laws. & 112 & $(6.1)$ \\
\hline 7 & Creating a generation that respects the environment. & 165 & $(9.0)$ \\
\hline 8 & $\begin{array}{l}\text { Promotion of the role of the media in raising environmental awareness, particularly focusing on satellite channels } \\
\text { that citizens often like to watch. }\end{array}$ & 90 & (4.9) \\
\hline 9 & The activation of the role of the environmental media in the education of citizens to protect the environment. & 69 & (3.8) \\
\hline 10 & Benefit from the developed countries' experience through information exchange and environmental programs. & 86 & (4.7) \\
\hline 11 & $\begin{array}{l}\text { Inclusion of the environment within the education curriculum and the development of environmental education } \\
\text { programs in schools for the education of children with a focus on preserving nature. }\end{array}$ & 90 & (4.9) \\
\hline 12 & $\begin{array}{l}\text { The organization of seminars for the education of mothers around some common mistakes that contribute to } \\
\text { harming the domestic environment. }\end{array}$ & 46 & $(2.5)$ \\
\hline 13 & Training teachers in order to raise their environmental awareness. & 48 & (2.6) \\
\hline 14 & $\begin{array}{l}\text { The environmental education of all of the categories of society (parents, teachers, students). For example, by the } \\
\text { development of a tree-planting competition with classes in the schools in cooperation with Muscat municipality, } \\
\text { teachers, school students, managers, and parents. }\end{array}$ & 82 & $(4.5)$ \\
\hline 15 & The provision of environmental information networks at the national level. & 31 & (1.7) \\
\hline 16 & The establishment of public seminars about the environment. & 28 & $(1.5)$ \\
\hline 17 & The organization of a number of awareness-raising lectures for reducing negative behavior or attitudes. & 30 & $(1.64)$ \\
\hline 18 & $\begin{array}{l}\text { The publication of magazines on regular basis that promote the environment, the publication of posters and } \\
\text { special magazines with the involvement of children and also the publication of paintings. }\end{array}$ & 28 & $(1.53)$ \\
\hline 19 & $\begin{array}{l}\text { Production of prints, videotapes, and games in the Arabic language for children to increase their environmental } \\
\text { awareness from a young age. }\end{array}$ & 42 & $(2.3)$ \\
\hline 20 & Offering abstract and concrete incentives through environmental competitions. & 29 & $(1.6)$ \\
\hline 21 & The provision of more facilities to the citizens in Muscat. & 32 & (1.7) \\
\hline 22 & $\begin{array}{l}\text { The development of hygiene campaigns and an increase in the role of the municipality and garbage collectors } \\
\text { regarding disposal of dead animals and landfill. }\end{array}$ & 76 & $(4.2)$ \\
\hline 23 & The organization of construction planning. & 23 & $(1.3)$ \\
\hline 24 & An increase in the role the municipality plays regarding the expansion of forested areas, gardens and parks. & 14 & $(0.8)$ \\
\hline 25 & Monitoring of industry/factories and all sources of pollution. & 31 & $(1.7)$ \\
\hline 26 & The treatment of garbage and the benefit from it when possible. & 24 & (1.3) \\
\hline 27 & Encouraging investment in environment-friendly business deals. & 10 & $(0.5)$ \\
\hline 28 & The promotion of public transport instead of the use of personal transport (i.e. cars). & 13 & $(0.7)$ \\
\hline 29 & $\begin{array}{l}\text { The creation of coordination between different Arab media in the environmental field and the presentation of } \\
\text { common environmental issues. }\end{array}$ & 5 & $(0.3)$ \\
\hline 30 & $\begin{array}{l}\text { The distribution of industrial zones among different Sultanate regions and their dimensions about the residential } \\
\text { assemblies. }\end{array}$ & 16 & $(0.9)$ \\
\hline 31 & $\begin{array}{l}\text { Increase in the role of the municipality regarding monitoring the farmers and their education regarding the } \\
\text { reduction of the use of chemical insecticides and promotion of the use of natural fertilizers. }\end{array}$ & 3 & $(0.2)$ \\
\hline
\end{tabular}

\section{CONCLUSIONS}

The results reveal that the public are lacking in their basic environmental knowledge. However, the public were more knowledgeable about local environmental problems such as pollution due to car exhausts and industrial plants. In addition, they were knowledgeable about international environmental problems such as climate change, global warming and the depletion of the ozone layer. Therefore, the results suggest more attention needs to be paid to basic environmental information dissemination to promote the public's knowledge to ensure that they take appropriate action. In addition, adequate knowledge may also help to produce appropriate behaviors. Hence, it is suggested that a more comprehensive awareness and education programme should be arranged by the Ministry of Regional Municipalities and Environment.

The findings also showed that the public had positive attitudes and behaviors toward the environment. There was a generally strong agreement 
Am. J. Environ. Sci., 4 (1): 39-49, 2008

amongst the public about the importance of protecting the environment. Most of the respondents being surveyed showed their willingness to do voluntary activities and their readiness to commit to environmental legislation for environmental protection and improvement. This might be attributed to the mass media such as television and newspapers. These media play an important role in forming the positive attitudes of the public towards the environment.

The present work is important since it is the first investigation that addresses the environmental awareness of the public in the Sultanate of Oman. The information obtained in the current study will be invaluable not only for assessing the present status of public environmental awareness in Oman, but also for improving the level of awareness and promoting environmental knowledge. In addition, the results of the paper are hoped to be a valuable resource to those involved with environmental awareness studies, especially in developing countries where such studies in this regard are inadequate. Further, the study can provide baseline information to decision makers with respect to the environmental awareness in Oman. Accordingly, the decision makers can use the public's opinions gained from this study as a guide for developing new programmes and designing policies affecting the environment and sustainable development. Moreover, the study can serve as a reference to track public trends on environmental awareness matters in the future.

Previous studies available in the open literature showed that environmental awareness was associated with various basic demographic variables such as sex, age, education level and family income. However, many of these studies indicated contradictory results among these variables. Debate continues around the associations between environmental awareness and these demographic variables. It is interesting to contribute to this debate by exploring the association between demographic variables and the public's environmental awareness in Oman. Hence, it is recommended that further study be undertaken to explore and shed some light on the role played by these basic demographic variables in order to better understand how such variables will shape the public's environmental awareness in the Sultanate of Oman.

The study provides baseline information on environmental knowledge and attitude residents of Oman. Once these baseline observations are collected, we recommend that a similar survey be repeated over subsequent years, focusing on the various population sectors, especially school age children, young mothers and fathers.

\section{REFERENCES}

1. United Nations, 1992. Agenda 21, United Nations Conference on environment and Development, Rio De Janeiro.

2. Sudarmadi, S., S. Suzuki, T. Kawada, H. Netti, S. Soemantri and A. Tugaswati, 2001. A survey of perception, knowledge, awareness, and attitude in regard to environmental problems in a sample of two different social groups in Jakarta, Indonesia. Environment, Development and Sustainability, 3: 169-183.

3. Ramsey, J.M., H.R. Hungerford and T.L. Volk, 1992. Environmental education in K-12 curriculum: Finding a niche. Journal of Environmental Education, 23(2): 35-45.

4. Tuna, M., 2004. Public environmental attitudes in Turkey. In C. Phillips (Ed.), Environmental Justice \& Global Citizenship, 1998. Oxford, United Kingdom: Inter-Disciplinary Press, pp: 11-20.

5. Easton, C.A., J.C. Avery, K.M. Staiger and J.B. Tindall, 1998. Environmental challenge: Public awareness. TAPPI Proceedings - Environmental Conference \& Exhibit, 3: 1105-1109.

6. Mittelstaedt, R., L. Sanker and B. VanderVeer, 1999. Impact of a week-long experiential education program on environmental attitude and awareness. Journal of Experiential Education, 22 (3): 138145.

7. Somma, M., S. Nikolai and T. Skopek, 1999. Attitudes toward economic development and the environment: A comparison of two West Texas cities. State \& Local Government Review, 31 (2): 135-141.

8. Borse, T.R., 2000. Environmental awareness of the villagers. Ecology, Environment and Conservation, 6 (4): 479-483.

9. Win, H.H., 2001. Environmental awareness and environmental education in Myanmar. Social Education, 65 (2): 98-101.

10. Zhenmin, F. and W. Xiaohua, 2002. Survey and evaluation on residents' environmental awareness in Jiangsu Province of China. International Journal of Environment and Pollution, 17(4): 312-322.

11. Arcury, T.A., 1990. Environmental attitude and environmental knowledge. Human organization, 49(4): 300-304.

12. Dunlap, R.E., 1992. Trends in public opinion toward environmental issues: 1965-1990. In R.E. Dunlap \& A.G. Mertig (Eds.), American environmentalism: The U.S. environmental movement, 1970-1990. Philadelphia: Taylor and Francis.

13. Gigliotti, L., 1994. Environmental issues: Cornell students' willingness to take action, 1990. Journal of Environmental Education, 26(1): 34-42. 
14. Chan, K., 1998. Mass media and environmental cognition in Hong Kong. Paper presented at the ICA/NCA conference. July 15-18, 1998, Rome, Italy.

15. Iizuka, M., 2000. Role of environmental awareness in achieving sustainable development. Prepared for the project "Enhancement of citizen's awareness in formulation of pollution control policies in major Latin American Cities, Environment and Human Settlements Division of ECLAC, with the support from the Government of Japan.

16. Tikka, P.M., M.T. Kuitunen and S.M. Tynys, 2000. Effects of educational background on students' attitudes, activity levels, and knowledge concerning the environment. Journal of Environmental Education, 31(3): 12-19.

17. Christine, C., 1990. The impact of television on public environmental knowledge concerning the Great Lakes. Master's Thesis, Ohio State University.

18. Schultz, C.J., 1994. The role of the mass media in extension and interpretation. International Journal of Environmental Education, 13 (4): 371-384.

19. Ramsey, C.E. and R.E. Rickson, 1976. Environmental knowledge and attitudes. Journal of Environmental Education, 8: 10-18.
20. Bradley, J.C., T.M. Waliczek and J.M. Zajicek, 1999. Relationship between environmental knowledge and environmental attitude of high school students. The Journal of Environmental Education, 30(3): 17-21.

21. Louis Harris and Associates, Inc., 1989. Public and leadership attitudes to the environment in four continents. A report of a survey in 16 countries, New York.

22. Asunta, T., 2003. Knowledge of Environmental Issues: Where pupils acquire information opinions, and how it affects their attitudes, and laboratory behavior, University of JYVÄSKYLÄ., Finland.

23. Ostman, R.E. and J.L. Parker, 1985. Awareness of, concern for, and perceived lifestyle effects of environmental messages in television and other mass media. Paper presented to The Popular Culture Association, April 3-7, Louisville, KY.

24. Haron, S.A., L. Pain and N. Yahaya, 2005. Towards sustainable consumption: An examination of environmental knowledge among Malaysians. International Journal of Consumer Studies, 29(5): 426-436. 